\title{
Open and Closed Borders: Is the New World Order Creating a System of Global Apartheid?
}

\author{
Anthony H. Richmond
}

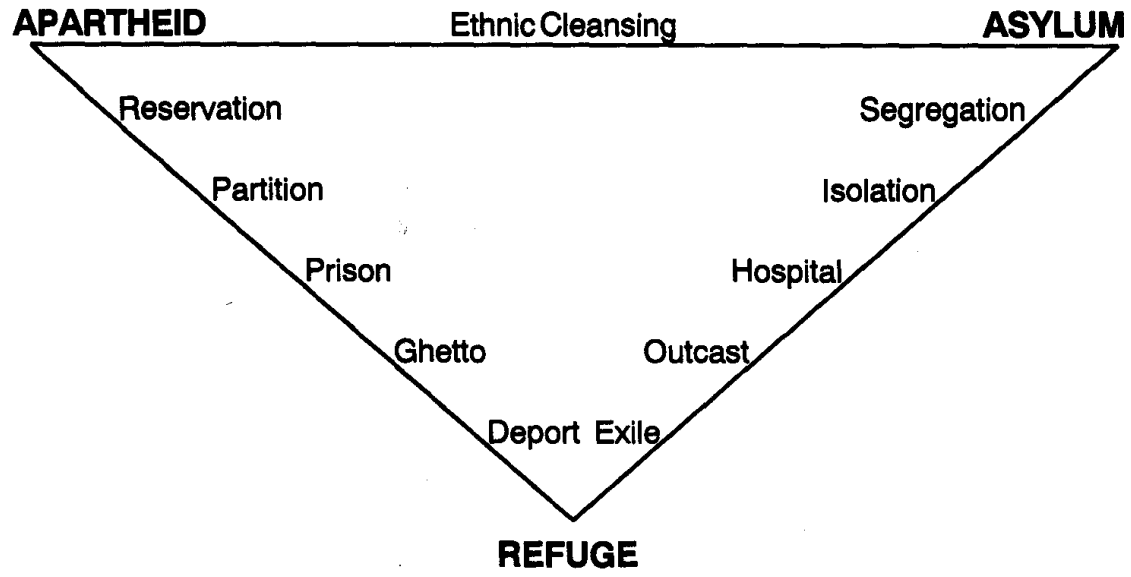

What do the above words have in common? From a sociological perspective, these are all actions, structures and institutions associated with forcible isolation of people who are different. Because of the differences, they are perceived as having actual or potential conflicting relationships. Distancing is used to deal with the conflict. When separation is imposed by a dominant group upon a less powerful one, the conflict is only temporarily resolved. In the long run the opposition is generally exacerbated. Restitution and retribution may be delayed for generations, but the power struggle continues.

It may seem shocking that apparently contradictory concepts such as "apartheid" and "asylum" should be juxtaposed, yet they have much in common. Literally, the word "apartheid" simply means "aparthood" (cf. neighbourhood) - that is, the separation of people into different areas. The term "asylum"

Anthony H. Richmond is emeritus professor of Sociology and senior scholar at the Centre for Refugee Studies. He acknowledges with thanks the award of a research and travel grant from $C R S$, which assisted in the collection of information for this article. (literally meaning nonseizure) originated with the church's refusal to allow wanted criminals and others sought by the authorities to be forcibly removed from the altar. Later the term was applied to mental hospitals, sanitoria and other institutions, where anyone who might contaminate others, disturb the peace, or in some way come into conflict with the general public, could be kept apart. Totalitarian states have long used the device of exile or forcible confinement in prisons or hospitals as a means of dealing with dissidents and political enemies. Thus "asylum" acquired a dual meaning. On the one hand, it is a way in which a more powerful or majority group segregates "others" who do not conform or who are seen as threatening. On the other hand, the asylum offers sanctuary and some protection for the minority or outcast, who might otherwise face the ultimate form of separation, that is, death.

The principle of separation as a means of social control is widely used and has a long history in Canada and elsewhere. The expulsion of the Acadians from the Maritimes in 1756 , the separation of Upper and Lower Canada, the creation of Indian reserves and, in some provinces, the formation of separate school systems for Catholics and Protestants, are all examples of the principle of separation being used as a device to reduce tension and maintain control. When South Africa introduced its system of African reserves (later called Bantustans or Homelands) it was following a well established precedent in colonial history. The English "Pale" in France and Ireland, the partition of Ireland and later India (establishing Pakistan and later Bangladesh), and the division of Cyprus, all are examples of the political application of the principle. The so-called "ethnic cleansing" of areas in former Yugoslavia is the latest example and one that comes close to genocide. Serbian, Croatian and Muslim peoples, who have lived together forcenturies, are being separated by military force in an attempt to create homogeneous ethno-religious areas, expanding the power and territorial control of fanatical nationalist leaders. Numerous civilian casualties and vast refugee movements are the result.

Residential segregation by ethnicity and religion created the ghettoes of European cities and eventually led to the Holocaust. In the United States, the emergence of separate residential areas (black ghettos) and separate schools for blacks and whites is another example. In 1954, the American Supreme Court found separate schools and colleges for Afro-Americans "inherently unequal" and therefore unconstitutional, but, despite busing, de facto residential and educational segregation have persisted. In some cases, electoral boundaries have been redrawn in order to emphasize ethnic homogeneity, thereby giving a spurious legitimacy to residential segregation. In determining the legitimacy of any case of ethnic segregation, it is necessary to consider the extent to which it is 
voluntary, on both sides, or how far it is a result of coercion and domination by one group over another. The latter is nearly always the case.

As far as immigration is concerned, the question is are we creating a system of global apartheid, based on discrimination against migrants and refugees from poorer developing countries? Or are we simply acting rationally to protect the integrity of our social systems and harmonize our immigration policies? Will the emerging "new world order" ensure justice and equality of treatment for immigrants and refugees, or will it create a system that gives privileges to some and deprives others of their rights? In order to determine whether it is accurate to describe present trends as contributing to "global apartheid," it is necessary to summarize the key elements in the South African experience concerning external and internal migration, in the context of state-legislated apartheid in that country.

\section{Apartheid in South Africa}

When the Nationalist party came to power in South Africa in 1948, building on existing forms of discrimination and segregation, it proceeded to create the system that came to be known as "apartheid." In defending the South African Group Areas Act in 1951, then President Dr. Malan argued that it was essential to keep the groups apart in order to maintain "racial peace" (Richmond 1961, 81137). An integral element of the system was the control of internal migration, combined with the selective immigration to South Africa of people who were racially defined as "European." Fortyfour years later, the system is gradually being dismantled, although South Africa is a long way from institutionalizing equality, democracy and racial integration.

Apartheid failed for a number of reasons, among which were the internal contradictions and conflicts within the system itself. Revolutionary change could only be contained by the use of excessive force, with consequent loss of legitimacy in the eyes of the world and its own people. Internal resistance to oppression was reinforced by pressure from outside the country. Externally imposed economic sanctions were used to symbolize disapproval of the regimeand to provide leverage for reform.

White South Africans are outnumbered by a ratio of six to one within the republic. They are an affluent and politically dominant minority who enjoy a standard of living comparable to that of middle-class Canadians, while the majority of the African population have average incomes that are only one-tenth of those of whites. This inequality has been maintained by systemic discrimination beginning with the Labour Regulation Act in 1911 that regulated the recruitment of labour and the Native Lands Act of 1913, which created the "Reserves," later to be described as "Homelands," confining the African population to 13 percent of ble by the white inhabitants" and not a threat to "the language, culture or religion of any white ethnic group," according to the minister of Immigration (Couper 1990). In fact, more than one million immigrants of European ethnic origin were admitted to South Africa between 1945 and 1985. At the same time, South Africa forced into exile many opponents of apartheid and hunted down Mozambican refugees who crossed the border, deporting those they caught (U.S. Committee for Refugees 1991, 53).

Notwithstanding these measures, the South African economy is dependent on a supply of temporary workers both from within and outside the country. Agriculture, mining, manufacturingand domestic services all rely heavily on migrant workers. These are drawn from

\section{As far as immigration is concerned, the question is are we creating a system of global apartheid, based on discrimination against migrants and refugees from poorer developing countries? Or are we simply acting rationally to protect the integrity of our social systems and to harmonize our immigration policies?}

the total area of the country. Subsequent legislation, up to and including the $A b O$ lition of Influx Control Act in 1986, regulated the movement of people into urban areas. Other measures included the Blacks (Urban Areas) Consolidation Act in 1945, the Population Registration Act in 1950 , which required everyone to carry racially-classified identification, the Group Areas Acts in 1950 and 1966, and the Prevention of Illegal Squatting Act in 1951. Added to these were a series of measures entrenching the dominanteconomic and political power of the white population by denying full citizenship and the franchise, suppressing political opposition and restricting access to education and social rights (Adam 1979).

The selective immigration of white settlers to South Africa was encouraged, in part to compensate for the demographic imbalance between white and nonwhite and to provide a source of skilled manpower. An immigrant to South Africa had to be "readily assimila- neighbouring countries, such as Malawi, Mozambique and Zambia, as well as from the "Homelands," such as Transkei, Ciskei, etc. Such migrant workers were confined to separate townships or to hostels away from the white areas. A third of the black population is now urban, but has no security of tenure. In 1981 it was estimated that 74,000 blacks commuted daily from "Homelands" into white areas to work, and a further 1.5 million worked for longer periods as contract labourers (Glavovic 1987, 47).

The South African situation gives rise to numerous external refugees and internally displaced persons. Opponents of apartheid were often obliged to flee to Swaziland or other neighbouring countries to avoid persecution. Compulsory removal to "Homelands," factional disputes within Bantustans and between tribal groups, together with squatter camps made up of those seeking employment, have created "internal refugees," whose numbers may range from 
hundreds of thousands to millions (Mabin 1987, 80-85). Despite some changes to the system, it seems that current trends represent "relatively insignificant changes from past apartheid policies" (Robertson 1987, 116). Meanwhile, the African National Congress is pressing the all-white government to introduce more radical reforms that will enable the nonwhite majority to participate democratically in the political process.

\section{Racism outside South Africa}

However, as apartheid in South Africa is gradually giving way to political reform and social change, the rest of the world appears to be moving in a different direction. In eastern and central Europe, following the collapse of the Soviet empire, nationalism and irredentism have revived, causing wide-

spread violence.

"Ethnic cleansing" provides the ideological rationale for civil war in the former $\mathrm{Yu}$ goslavia. The idea that only one dominant ra-

cial or ethno-religious group should be allowed to occupy a particular territory is precisely the meaning of apartheid. When military force is used to bring about such territorial separation, kjlling or displacing hundreds of thousands (possibly millions) of people in the process, it is no exaggeration to speak of "apartheid."

Faced with the prospect of mass migration from poorer to richer countries, from those where governmental systems have collapsed to those with more stable political environments (and with huge refugee flows from BosniaHerzegovina) coordinated efforts are being made to stem the potential flow into western Europe. The legislation used and the regulative institutions created have a remarkable similarity to those that South Africa adopted to control the movement of people from outside and withinits borders. Furthermore, the ideological justifications used to defend these measures echo those adopted by the dominant white minority in South Africa to defend their actions in impos- ing the system of apartheid on the nonwhite majority. As well as explicit racism and claims to "superiority," they include an obligation to limit intertribal conflict, the need to preserve ethnicidentity, expressions of religious fanaticism, the defence of existing cultural and social institutions, state security, the maintenance of law and order, preservation of economic privilege and the need to regulate and manage population movements. These themes, which were constantly repeated by defenders of the South African system, are now recurring in the rhetoric of those who wish to restrict immigration into western Europe, North America and Australia.

People in most countries exhibit an ambivalent attitude towards questions of race, ethnicity and migration. On the one hand, the United Nations Sub-Com-

violence in Germany in 1992, much of it instigated by neo-Nazi "skinheads," targeted towards asylum applicants, Gypsies and other foreigners, including long resident Turkish workers and their families. The government reacted by proposing stricter controls over immigration and an amendment to the constitutional right to asylum. The Republican Party in Germany proposed mass repatriation of foreigners and the confinement of accepted refugees in camps away from cities.

\section{Immigration Controls}

There is a worldwide trend towards stricter immigration controls and attempts to limit the flow of refugees and asylum applicants. It is part of a growing nostalgia for a simpler world in which people felt secure in homogeneous communities where neighbours shared "traditional" values. It is also a reaction to the insecurity felt by many faced with a rapidly changing global society. This is

mission on Prevention of Discrimination and Protection of Minorities and the Commission on Human Rights condemn apartheid and, on the other, they note an upsurge in racism, discrimination, intolerance and xenophobia in many parts of the world (Human Rights Newsletter, October 1990 and April 1991). In Europe and North America neo-Nazi and other right-wing extremist groups are gaining support. Recent riots in Los Angeles and lesser outbreaks of violence in Toronto serve to remind us how volatile interracial situations are. Publicopinion surveys in many countries reveal a backlashagainstimmigration and growing support for reactionary political parties. In France, the Front National, led by Jean-Marie Le Pen, mobilized 15 percent of the popular vote in recent elections, and demonstrations against nonwhite immigrant workers are a frequent event, as are antiracist marches (Singer 1991; Husbands 1991). In Germany, a tenfold increase in racist attacks (from 200 to 2,386) was reported in 1991 (Cruz 1992). There was a further escalation of ethnic evident in the growth of racism, xenophobia, religious and ethnic conflict in various countries, including those that have traditionally been receptive to both political and economic migrants. Politically, it is expressed in the coordinated efforts of countries in western Europe, North America and Australia to deter asylum applications and limit mass migration to these regions. There is a growing fear in Europe concerning the possibility of mass migration from east to west and an equal concern about the potential flow from south to north, including those from Mahgreb territories of the southern Mediterranean and Africa to France and Germany.

The reunification of East and West Germany reduced the Federal Republic of Germany's dependency on immigrant workers while, at the same time, leaving the country vulnerable to mass migration from east and central Europe, as well as from the former Soviet Union. Under the German constitution, "ethnic Germans," from wherever they may come, have privileged rights ofentry and 
of citizenship, although long-time residents of the country, who are not of German descent (including their children born in Germany) are denied similar privileges. Recently, new immigration legislation was introduced in Germany that will severely restrict the number of asylum applicants accepted and allows the government to segregate them in camps. Britain introduced an asylum bill that will require refugees to be fingerprinted, restrict access by asylum applicants to public housing, permit deportation when an asylum claim has been refused, and require airlines or other carriers to ensure that travellers have visas to enter or even to pass through the United Kingdom en route to another country.

Notwithstanding the European Economic Community's abolition of internal border checks in January 1993, Britain, Ireland and Denmark have expressed reservations and indicated exceptions. The U.K. intends to retain frontier controls for all non-EC nationals, including those entering $B$ ritain via other EC countries. A limit of three months' stay will be placed on non-U.K. nationals entering the country. Britain is one of the twelve European countries that signed the Dublin Convention in June 1990. Neither this, nor the related Schengen Agreement, have yet been ratified by all the countries involved, although their provisions are expected to come into force in 1993.

\section{Schengen and Dublin Conventions}

The Schengen Agreement was signed in 1985 by Belgium, Denmark, France, Germany and Luxembourg. When the subsequent Dublin Agreement is ratified, it will apply to all twelve EEC members. The agreement provides that persons with valid documents, who can show that they have sufficient means to support themselves during their stay and to return to their country of origin, will be allowed entry, but only if they are not considered a "threat to public policy, national security or international relations of the Contracting Parties." Once admitted, they may travel freely within the EEC, subject to any limitations that Britain or other dissenting countries may impose. In order to enforce the regulations, the countries in question may take any necessary steps to verify documents, and may use mobile units to exercise surveillance at external borders. Every contracting party is obliged to supply the others with information concerning individuals requesting admission (including asylum applicants) and this information may be computerized.

As well as extending the provisions of the Schengen Agreement to all countries in the EEC, the Dublin Convention also deals specifically with the question of asylum applicants and determines who is responsible for processing them. It reiterates the 1951 Geneva Convention's definition of a refugee, as amended by the 1967 New York Protocol. In order of precedence, the state responsible for hearing an asylum application is either the one that issued a residence permit or an entry visa; when no visa is required, national policing and security. The Trevi Groupis an intergovernmentalbody that coordinates efforts to combat terrorism and organized crime. Among the measures it has recommended, and that are being widely adopted, are uniform documentation of travellers, the fingerprinting of migrants and asylum applicants, the creation of a computerized database and information exchange on criminals, deported persons and persons non grata, training of police officers and border guards for surveillance, and the harmonization of legislation governing immigration and security measures at borders.

It is probably not a coincidence that many of these measures have been incorporated into the new Canadian legislation on immigration (Bill C-86). Canada is one of the sixteen states participating in the Intergovernmental Consultations on Asylum, Refugee and Migration Policies

\section{Critics of the Schengen and Dublin agreements note that there is no recognition of the growing numbers of cases of de facto humanitarian refugees, who may not meet the 1951 Convention definition.}

the state that first admitted the person into the Community territory is responsible. The other states of the Community are bound by the decision of the one that processes the application.

Critics of the Schengen and Dublin agreements note that there is no recognition of the growing numbers of cases of de facto humanitarian refugees, who may not meet the 1951 Convention definition. It is felt that the effect of visa requirements, entry regulations and carrier sanctions will be to deter or exclude many legitimate claimants and those trying to escape war-torn countries. It will also increase the traffic in forged documents. Third country nationals (i.e., non-EEC citizens) resident in the EEC will find their right to travel and to work in other countries restricted. These agreements must also be considered in the context of increasing cooperation, within and between European countries and others in matters of inter- in Europe, North America and Australia. Described as "informal," these consultations enable governments to be kept informed of developments in other countries and facilitate the harmonization process. The participating states acknowledge the value of cooperation, endorse the principles established in the Dublin Convention, and seek to intensify cooperation in combattingillegal immigration. The aim is to adopt a concerted approach that will alsoinclude the countries of eastern Europe, so that they will adopt policies that correspond with those in western Europe.

Canada's new Immigration Act enables this country to harmonize its immigration law and practice with that of other countries. As in the McCarthy era in the United States, "guilt by association" with allegedly subversive organizations or a criminal record, however minor, will be sufficient to exclude potential immigrants and asylum appli- 
cants. Asylum applicants will be fingerprinted and the use of forged documents will be grounds for exclusion. Immigrants may be required to work in particular places and to remain in such employment for two years after arrival, as if they were indentured. Business immigrants and investors will be given top priority for admission. Officials will have greater control over numbers admitted annually in various categories. As at present, the extensive use of temporary employment visas will enable the government to limit the number of people allowed to settle permanently. None of these measures, in themselves, appears particularly draconian. However, the combined effect will be to give considerable advantage to the wealthy and well the Americas and Oceania are outnumberedin the worldin a ratio of four toone. This leads to fear that they will lose their power and territorial control, as the peoples of Africa and Asia restructure their economies and participate in a global postindustrial society where mass migration is the norm. As the senior legal adviser to the UNHCR has stated, even if the developed countries "were prepared to betray the very values on which their societies are based, by building new iron curtains and Berlin Walls around their common territory, the human flood would still find its ways" (von Blumenthal 1991). In other words, a system of global apartheid is bound to fail.

What then is the alternative? The director of the agency for Intergovernmen-

\section{Contrary to the view that economic growth will itself remove the need for migration, it must be recognized that the emerging global economic and social system is one in which population movements will continue to increase rather than decline.}

educated over "your tired, your poor, your huddled masses yearning to breathe free." The delayed reaction of Canada and many other countries to the prolonged plight of refugees in Somalia and other regions of Africa, compared with the response to those in former Yugoslavia, suggests that the "huddled masses" should preferably be white, if they are to receive much help at all. The United States (in the Bush and Clinton administrations) has applied a double standard in its treatment of Cuban as compared with Haitian asylum applicants. "Fortress Europe" is matched by "Fortress North America."

\section{Conclusion}

We are living in a global society, although we still lack effective world governmentalinstitutions. Nevertheless, the most economically developed and affluent countries are banding together to protect their privileged position in much the same way that Afrikaners and others of European descent sought to maintain their dominance in South Africa. Europeans and those of European descent in tal Consultations echoes the view of many experts that uncontrolled, largescale international migration threatens social cohesion, international solidarity and peace (Widgren 1991). Coordinated efforts to deter irregular movements, encourage voluntary repatriation, harmonize immigration and asylum policies, and promote economic developmentin the ThirdWorld are seen as essential. But the economic, political and social costs of effective measures to deal with root causes are enormous. They would involve long-term developmental assistance, large-scale planned migration and concerted efforts to promotehuman rights and equality, in sending and receiving countries alike. Contrary to the view that economic growth will itself remove the need for migration, it must be recognized that the emerging global economic and social system is one in which population movements will continue to increase rather than decline. A comprehensive nonexodusapproach, such as that advocated by the Intergovernmental Committee and its advisers, will be self-defeating.
Global apartheid will collapse as surely as the South African version has done. In the postmodern world we must all learn to live with ethnocultural diversity, rapid social change and mass migration. There is no peaceful alternative.

\section{References}

Adam, Herbert. 1979. Ethnic Power Mobilized: Can South Africa Change? New Haven, Connecticut: Yale University Press.

Couper, Michael P. 1990. "Immigrant Adaptation in South Africa." Unpublished doctoral dissertation, Rhodes University, South Africa.

Cruz, A., ed. 1992. Migration News Sheet.

Glavovic, P.D. 1987. "State Policy, Agriculture and Environmental Values." In Race and the Law in South Africa, edited by A.J. Rycroft et al. Cape Town, South Africa: Juta.

Human Rights Newsletter. 1991. "Commission on Human Rights Concludes Annual Session," April.

Husbands, Christopher T. 1991. "The Support for the Front National: Analyses and Findings." Ethnic and Racial Studies 14, no. 3.

Mabin, Alan. 1987. "Unemployment, Resettlement and Refugees in South Africa." In Refugees: A Third World Dilemma, edited by J.R. Rogge. Totowa, New Jersey: Rowman \& Littlefield.

Richmond, Anthony. 1961. The Colour Problem: A Study of Racial Relations. Harmondsworth, England: Penguin Books.

Robertson, M.K. 1987. "Orderly Urbaniza tion: The New Influx Control." In Race and the Law in South Africa, edited by A.J. Rycroft et al. Cape Town, South Africa: Juta.

Singer, Daniel. 1991. “The Resistable Rise of Jean-Marie Le Pen." Ethnic and Racial Studies 14, no. 3.

U.S. Committee for Refugees. 1991. World Refugee Survey, 1991. Washington, D.C.: U.S. Committee for Refugees.

von Blumenthal, Ulrich. 1991. "Dublin, Schengen and the Harmonization of Asylum in Europe." A paper presented at the First European Lawyers Conference, Brussels, February 14-15.

Widgren, Jonas. 1991. "The Management of Mass Migration in a European Context." Statement at the Royal Institute of International Affairs, London, England, March 12. 